\title{
MOTIVASI PEMILIHAN LINTAS MINAT SAINS PADA SISWA JURUSAN ILMU SOSIAL
}

\author{
Yendrita \\ STKIP Yayasan Abdi Pendidikan Payakumbuh \\ yen29drita@gmail.com
}

Submit, 10-11-2019 Accepted, 23-12-2019 Publish, 24-12-2019

\begin{abstract}
Social Sciences Department of SMA N I Suliki District in choosing cross-interest of Science. This type of research is quantitative research with descriptive methods. The research instrument is a set of questionnaire. Samples were taken with a total sampling technique, then the subjects of this study were all students of class X majoring in Social Sciences who chose cross interest of Science, amounting to 126 people, data analysis technique is a percentage technique. Based on the results of data analysis, intrinsic motivation that influences the selection of cross-student interests is as follows: based on ideals of $70.58 \%$, based on student abilities of $69.44 \%$, based on student conditions of $70.33 \%$, based on interests of $66.93 \%$, based on the attitude of $75.06 \%$, while extrinsic motivation that influences the selection of students' cross-interest is as follows; based on family encouragement of $62.56 \%$, encouragement of friends $59.32 \%$, employment opportunities of $69.57 \%$ and opportunities to continue study $61.50 \%$. Whereas based on sub-variables, intrinsic motivation was found to influence the cross-selection of scientific interest by $70.48 \%$ (in the good category) and extrinsic motivation by $62.75 \%$ (in the good category). The conclusions of this study are: intrinsic motivation influences students more in crossing scientific interests than extrinsic motivation
\end{abstract}

Keywords: Motivation, SAINS Cross-Interest Selection,

\begin{abstract}
Abstrak: penelitian ini bertujuan untuk mengetahui bagaimana motivasi instrinsik dan ekstrinsik mempengaruhi siswa jurusan Ilmu sosial SMA N I Kecamatan Suliki dalam memilih lintas minat Sains. Jenis penelitian ini adalah penelitian kuantitatif dengan metode deskriptif. Instrumen penelitiannya adalah seperangkat angket. Sampel diambil dengan teknik total sampling, maka subjek penelitian ini adalah seluruh siswa kelas X jurusan Ilmu Sosial yang memilih lintas minat Sains yang berjumlah 126 orang, Teknik analisa data adalah teknik persentase. Berdasarkan hasil analisis data, motivasi intrinsik yang mempengaruhi pemilihan lintas minat siswa sebagai berikut : berlandaskan cita - cita sebesar 70,58\%, berlandaskan kemampuan siswa sebesar 69,44\%, berlandaskan kondisi siswa sebesar 70,33\%, berlandaskan minat sebesar 66,93\%, berlandaskan sikap sebesar 75,06\%, sedangkan motivasi ekstrinsik yang mempengaruhi pemilihan lintas minat siswa adalah sebagai berikut; berlandaskan dorongan keluarga sebesar 62,56\%, dorongan teman 59,32\%, peluang kerja sebesar 69,57\% dan peluang melanjutkan studi $61,50 \%$. Sedangkan berdasarkan sub variable, didapatkan motivasi instrinsik mempengaruhi pemilihan lintas minat sains sebesar 70,48\% (dengan kategori baik) dan motivasi ekstrinsik sebesar 62,75\% (dengan kategori baik). Simpulan penelitian ini adalah :motivasi instrinsik lebih mempengaruhi siswa dalam memilih lintas minat sains dari pada motivasi ekstrinsik
\end{abstract}

Kata Kunci : Motivasi, Pemilihan Lintas Minat SAINS

\section{PENDAHULUAN}

Kurikulum 2013 memberikan beberapa perubahan dalam system pendidikan. Salah satunya, adalah perubahan yang terjadi di SMA adalah penjurusan yang tidak lagi dilakukan pada kelas XI, melainkan mulai dari
Kelas X. Disamping penjurusan, siswa harus memilih mata pelajaran lintas minat.Untuk siswa jurusan ilmu social disediakan mata pelajaran lintas minat dari kelompok mata pelajaran Ilmu Pengetahuan Alam diantaranya: matematika dan mata pelajaran Sains, 
Bahasa Jepang, Bahasa Inggris dan Ekonomi.Sebaliknya peminatan untuk jurusan IPA adalah mata pelajaran dari kelompok Ilmu social.

Menurut Permendikbud Nomor 69 tahun 2013 tentang Kerangka Dasar dan Struktur Kurikulum SMA/MA, bahwa pemilihan kelompok peminatan didasarkan pada nilai rapor SMP/MTs, nilai Ujian Nasional (UN) SMP/MTs, rekomendasi guru bimbingankonseling di SMP, hasil tes penempatan ketika mendaftar di SMA, dan hasil tes bakat minat oleh psikolog. Kondisi ini memungkinkan bagi siswa Jurusan Ilmu Sosial untuk mengambil peminatan ilmu-ilmu sains, matematika dan bahasa.

Meskipun siswa dimungkinkan mengikuti mata pelajaran lintas minat yang bersebrangan dengan jrusanya, namun alokasi waktu belajarnya sangat terbatas. Waktu yang diberikan untuk mata pelajaran lintas minat di kelas $\mathrm{X}$ hanya sekitar 4 jam pelajaran $\mathrm{x} 45$ menit perminggu, dengan keterbatasan waktu serta posisi sebagai mata pelajaran lintas minat tentu ada perbedaan muatan yang diberikan antara mata pelajaran wajib dengan peminatan.

Pemilihan peminatan tidak terlepas dari motivasi yang dimiliki siswa baik motivasi instrinsik maupun motivasi ekstrinsik. Begitu juga dengan siswa jurusan ilmu social di SMA N I Kecamatan suliki, mereka memilih peminatan sains dengan motivasi yang berbeda - beda, mungkin ada yang memilih peminatan sains karena motivasi instrinsik yang berlandasan cita- cita, kemampuan yang dimilikinya,kondisi siswa,minat serta sikap. Disamping itu mungkin juga karena motivasi ekstrinsik yang berlandasan dorongan keluarga, dorongan teman, peluang kerja dan peluang melanjutkan studi.
Penelitian yang relevan yaitu penelitian yang dilakukan oleh Ade (2014) bahwa siswa jurusan ilmu sosial memilih lintas minat biologi karena siswa merasa lebih mudah memahaminya, penelitian ini hanya melihat apa motivasi siswa jurusan Ilmu sosial dalam memilih peminatan biologi.

Sedangkan dalam penelitian ini akan terlihat dengan jelas prentase setiap indikator dari motivasi instrinsik dan ekstrinsik yang mempengaruhi siswa jurusan ilmu sosial dalam memilih lintas minat sains.

\section{LANDASAN TEORI}

Program peminatan merupakan suatu proses pemilihan dan penetapan peminatan siswa pada kelompok mata pelajaran. Program Lintas minat memberikan kesempatan kepada siswa untuk mengembangkan mintanya pada suatu mata pelajaran tanpa dibatasi pada program penjurusan.

Hal ini dijelaskan Kemendikbud bahwa untuk kurikulum 2013, siswa selain memilih mata pelajaran dalam suatu kelompok tertentu, siswa juga diberikan kesempatan untuk mengambil mata pelajaran dari kelompok peminatan lain (Kemendikbud, 2013) .Selanjutnya ditambahkan kembali bahwa lintas minat adalah program kurikuler yang disedediakan untuk mengakomodasi perluasan pilihan minat,bakat dan kemampuan akademik peserta didik dengan orientasi penguasaan kelompok mata pelajaran keilmuan di luar pilihan minat (Kemendikbud, 2015)

Pemeilihan lintas minat ini tidak terlepas dari pengaruh motivasi yang dimiliki siswa , baik motivasi instrinsik mapun motivasi ekstrinsi. Motivasi intrinsik adalah motif - mmotif yang menjadi aktif dan tidak perlu diransang dari luar,karena di dalam diri setiap 
individu sudah ada dorongan untuk melakukan sesuatu (Sardiman: 2010).

Motivasi instrinsik terdiri dari beberapa indicator diantaranya : cita cita,kemampuan siswa, kondisi diri siswa, minat serta sikap. Sebagaimana yang dikatakan (Dimyati, 2002) bahwa Unsur-unsur yang mempengaruhi motivasi instrinsik adalah cita - cita atau aspirasi, kemampuan siswa dan kondisi fisik dan rohani siswa. Selanjutnya Djaali (2011) menjelaskan lagi bahwa minat adalah "rasa lebih suka dan rasa ketertarikan pada sesuatu hal atau aktivitas, tanpa ada yang menyuruh. Jadi minat adalah ketertarikan secara alami terhadap sesuatu tanpa ada pengaruh dari luar diri individu.

Selanjutnya sikap adalah tindakan yang mengarah kepada objek atau juga kejadian. Sebagaimana yang dikatakan Uno (2012) Sikap adalah “ Gejala internal berupa kecendrungan untuk mereaksi atau merespon dengan cara yang relative tetap terhadap suatu objek, bak berupa orang, barang dan sebagainya".Jadi bisa diartikan bahwa sikap adalah suatu keadaan dari dalam diri seseorang untuk menentukan keputusan.

Selain motivasi instrinsik, pemilihan lintas minat juga dipengaruhi motivasi ekstrinsik,Motivasi ekstrinsik adalah motif- motif yang aktif dan berfungsi karena ada ransangan dari luar diri seseorang (Sardiman, 2010). Bahkan sebelumnya Dimyati (2002) telah menjelaskan juga bahwa motivasi ekstrinsik adalah " dorongan terhadap prilaku sesorang yang ada di luar perbuatan yang dilakukannya".Berarti motivasi ekstrinsik adalah dorongan yang berasal dari luar diri seseorang.

Ada beberapa hal yang menyebabkan seseorang berbuat karena dorongan dari luar dirinya, begitu juga dengan siswa jurusan ilmu sosial dalam memilih lintas minat sains. Motivasi ekstrinsik yang bisa mempengaruhi siswa dalam pemilihan lintas minat sains adalah dorongan keluarga, dorongan teman, peluang kerja dan peluang untuk melanjutkan studi.

\section{METODE PENELITIAN}

Sebelum melaksanakan penelitian terlebih dahulu telah dilaksanakan observasi ke lokasi penelitian . Berdasarkan observasi yang dilaksanakan pada tanggal 16 Februari 2017 ternyata di sekolah SMA N I Kecamatan Suliki ada beberapa lintas minat yang disediakan untuk siswa jurusan ilmu social,diantaranya :matematika, ekonomi, bahasa Jepang, bahasa Ingris dan Mata Pelajaran Sains. Siswa jurusan Sosial yang memilih lintas minat Sains hanya kelas X dan Kelas XII. , Sesuai dengan latar belakang di atas dan juga berdasarkan bidang keahlian peneliti, maka penelitian ini dilakukan dengan terhadap seluruh siswa Kelas X jurusan Ilmu Sosial SMA N I Suliki yang memilih lintas minat Sains, yang berjumlah 126 orang siswa

Instrumen penelitian yang digunakan adalah angket, yang disusun sendiri oleh peneliti. Angket yang digunakan berupa angket tertutup. Sebelum dijadikan instrument penelitian terlebih dahulu angket tersebut telah di uji coba di kelas XII pada sekolah yang sama. Dari hasil uji coba telah ditentukan reliabilitas angket.. Uji coba angket dianalisis dengan menggunakan rumus Alpha

Hasil analis uji coba angket, didapatkan reliabilitas angket 0,82 ( sangat tinggi). Selanjutnya angket disebar kepada sampel dan dianalisis dengan menggunakan rumus teknik persentase

$$
S=\frac{R}{N} x 100 \%
$$


Keterangan :

$\mathrm{S}=$ Nilai yang diharapkan (dicari)

$\mathrm{R}=$ Jumlah skor dari item pernyataan yang dijawab

$\mathrm{N}$ = Jumlah skor maksimum

$100 \%=$ Angka ketetapan persentase

Setelah diketahui persentasenya maka dikonsultasi ke tabel interpresentasi sebagai berikut :

Tabel Kriteria Interpresentasi Skor

\begin{tabular}{ll}
\hline Persentase & Kriteria \\
\hline $81 \%-100 \%$ & Baik sekali \\
\hline $61 \%-80 \%$ & Baik \\
\hline $41 \%-60 \%$ & Cukup baik \\
\hline $21 \%-40 \%$ & Kurang baik \\
\hline $0 \%-20 \%$ & Tidak baik \\
\hline
\end{tabular}

Setelah dikonsultasi ke tabel kriteri interpresentasi di atas, maka didapatkan kesimpulan penelitian.

\section{HASIL PENELITIAN}

Hasil penelitianterhadap motivasi pemilihan lintas minat SAINSpada siswa jurusan Ilmu Sosial SMAN 1 Kecamatan Suliki tahun ajaran 2017/2018 adalah sebagai berikut :

Tabel 2 Hasil Analisa Data

\begin{tabular}{|c|c|c|c|c|c|}
\hline No & Indikator & $\begin{array}{l}\text { Jumlah } \\
\text { Skor }\end{array}$ & $\begin{array}{l}\text { Skor } \\
\text { Maks }\end{array}$ & $\begin{array}{l}\text { Persen } \\
\text { tase } \\
\text { Sub } \\
\text { Indika } \\
\text { tor } \\
\end{array}$ & Kategori \\
\hline & \multicolumn{5}{|l|}{ Instrinsik } \\
\hline 1. & Cita-cita & 1423 & 2016 & 70,58 & Baik \\
\hline 2. & $\begin{array}{l}\text { Kemampua } \\
\text { n Siswa }\end{array}$ & 1050 & 1512 & 69,44 & Baik \\
\hline 3. & $\begin{array}{l}\text { Kondisi } \\
\text { Siswa }\end{array}$ & 709 & 1008 & 70,33 & Baik \\
\hline 4. & Minat & 1012 & 1512 & 66,93 & Baik \\
\hline 5. & Sikap & 1135 & 1512 & 75,06 & Baik \\
\hline \multicolumn{6}{|c|}{ Ekstrinsik } \\
\hline 6. & $\begin{array}{l}\text { Dorongan } \\
\text { keluarga }\end{array}$ & 946 & 1512 & 62,56 & Baik \\
\hline 7. & $\begin{array}{l}\text { Dorongan } \\
\text { teman }\end{array}$ & 1196 & 2016 & 59,32 & $\begin{array}{l}\text { Cukup } \\
\text { Baik }\end{array}$ \\
\hline 8. & $\begin{array}{l}\text { Peluang } \\
\text { Kerja }\end{array}$ & 1052 & 1512 & 69,57 & Baik \\
\hline 9. & $\begin{array}{l}\text { Peluang } \\
\text { melanjutka } \\
\text { n studi }\end{array}$ & 1550 & 2520 & 61,50 & Baik \\
\hline
\end{tabular}

Tabel 2 memperlihatkan hasil analisa data terhadap motivasi dalam pemilihan lintas minat Sains bagi siswa jurusan Ilmu Sosial SMA N.I Suliki berdasarkan masing-masing indikator, adalahkarena cita-cita sebesar 70,58\% dengan kategori baik, Karena kemampuan siswa sebesar 69,44\% dengan kategori baik, karena kondisi siswa sebesar 70,33\% dengan kategori baik, karena minat sebesar 66,93\% dengan kategori baik dan karena Sikap sebesar 75,06\% dengan kategori baik.

Selanjutnya karena dorongan keluarga sebesar $62,56 \%$ dengan kategori baik, karena dorongan teman sebesar 59,32\% dengan kategori cukup baik, karena peluang kerja sebesar $69,57 \%$ dengan kategori baik, karena peluang melanjutkan studi sebesar $61,50 \%$ dengan kategori baik.

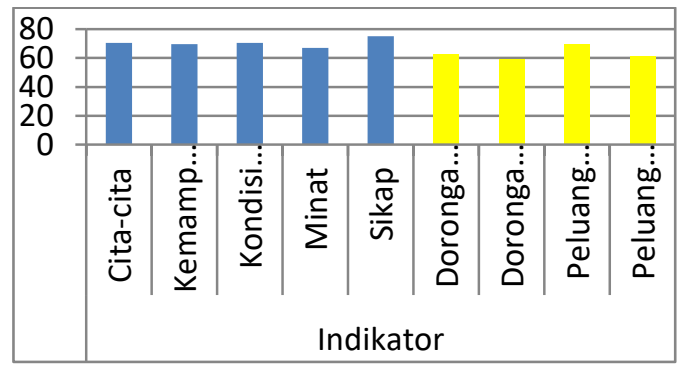

Grafik 1 Persentase Jawaban Angket Siswa

Grafik I maka dapat diketahui persentase memilih SAINS karena motivasi instrinsik yang tertinggi terletak pada indikator sikap, kemudian diikuti cita-cita, kondisi siswa, kemampuan siswa dan minat. Sedangkan, persentase memilih SAINS karena motivasi ekstrinsik yang tertinggi terletak pada indikator peluang kerja, dorongan keluarga, peluang melanjutkan studi dan dorongan teman.

Berdasarkan hasil analisis per indikator sebagaimana yang telah dijelaskan di atas, maka didapatlah analisis berdasarkan sub variable seperti yang ada pada tabel 3 di bawah ini : 
Tabel 3 Hasil Analisis Data

\begin{tabular}{|c|c|c|c|c|c|}
\hline Variabel & Sub Variabel & $\begin{array}{l}\text { Jum } \\
\text { lah } \\
\text { Skor }\end{array}$ & $\begin{array}{l}\text { Skor } \\
\text { Maks }\end{array}$ & $\begin{array}{l}\text { Perse } \\
\text { ntase } \\
\text { Sub } \\
\text { Varia } \\
\text { bel }\end{array}$ & Kategori \\
\hline $\begin{array}{l}\text { Motivasi } \\
\text { siswa } \\
\text { jurusan } \\
\text { ilmu sosial }\end{array}$ & $\begin{array}{l}\text { Memilih } \\
\text { SAINS karena } \\
\text { motivasi } \\
\text { instrinsik }\end{array}$ & 5329 & 7560 & 70,48 & Baik \\
\hline $\begin{array}{l}\text { (IS) dalam } \\
\text { memilih } \\
\text { lintas } \\
\text { minat } \\
\text { SAINS di } \\
\text { SMAN 1 } \\
\text { Kecamata } \\
\text { n Suliki }\end{array}$ & $\begin{array}{l}\text { Memilih } \\
\text { SAINS karena } \\
\text { motivasi } \\
\text { ekstrinsik }\end{array}$ & 4744 & 7560 & 62,75 & Baik \\
\hline
\end{tabular}

Tabel 3 memperlihatkan hasil analisis data dalam pemilihan lintas minat sains oleh siswa jurusan Ilmu Sosial SMA N.I Suliki adalah sebagai berikut, bahwa memilih sains karena motivasi instrinsik lebih tinggi dengan persentase $70,48 \%$ (dengan kategori baik) dibandingkan dengan motivasi ekstrinsik yang hanya sebesar $62,75 \%$ (dengan kategori baik).

\section{PEMBAHASAN}

Hasil analisis data memperlihatkan bahwa motivasi siswa memilih lintas minat sains adalah baik. Hal ini terbukti dari skor yang diperoleh berada pada rentang 61\%-80\%. Berdasarkan Riduwan (2011) skor tersebut dikategorikan baik. Dilihat dari motivasi instrinsik, motivasi yang tinggi mempengaruhi minat siswa dalam memilih sains adalah dari indikator sikap yaitu sebesar 75,06\% (baik) Sikap merupakan kecendrungan untuk merespon terhadap sesuatu, sikap yang dimiliki siswa dapat memberikan penilaian tentang peminatan sains, yang mengakibatkan terjadinya sikap menerima dan mengambil keputusan untuk memilih lintas minat sains (Uno, 2012). Siswa bersikap menerima peminatan sain, mungkin karena mereka merasa materi sains banyak yang berguna dalam kehidupan sehari - hari. Seperti materi pelajaran biologi,fisikan dan juga kimia.

Setelah sikap, pemilihan lintas minat juga dipengaruhi oleh cita-cita yaitu sebesar 70,58\% (baik) berarti siswa ilmu social juga ada yang bercita - cita pada kelompok Ilmu Pengetahuan Alam.

Selanjutnya kondisi siswa yaitu sebesar 70,33\% ( baik) dengan arti kata siswa dipengaruhi oleh kondisi jasmani dan rohaninya dalam pemilihan peminatan sains. Tidak bisa dipungkiri keadaan jasmani dan rohani akan menentukan seseorang dalam memilih segala sesuatunya,keadaan jasmani dan rohani seorang tidaklah sama.

Kemudian disusul oleh Kemampuan siswa yaitu sebesar $69,44 \%$ (baik), berarti dalam pemilihan peminatan sains juga dipengaruhi oleh kecakapan seorang siswa.Motivasi intrinsik yang paling rendah pengaruhnya dalam pemilihan peminatan sains adalah minat yaitu sebesar 66,93\% (baik), Berarti indikator minat merupakan indicator yang paling rendah dalam mempengaruhi pemilihan lintas minat sains, dengan kata lain, walau para siswa mempunyai sikap positif terhadap mata pelajaran sains, belum tentu siswa tersebut suka untuk memelih sebagai peminatan. Berdasarkan hal tersebut maka siswa jurusan Ilmu social SMA N I Kecamatan Suliki memiliki motivasi instrinsik terhadap mata pelajaran Sains adalah 70,48\% (baik)

Motivasi ekstrinsik yang mempengaruhi pemilihan peminatan sains adalah sebesar 62,75\% (baik) sedangkan Indikator motivasi ekstrinsik yang paling dominan adalah berlandasakan peluang kerja yaitu 69,57\% (baik) Menurut KBBI (Kamus Besar Bahasa Indonesia), peluang memiliki arti sama dengan kesempatan. 
Kesempatan adalah celah yang dapat dimanfaatkan oleh seseorang yang memiliki kriteria sesuai dengan yang ditetapkan. Menurut Gilarso (2008), kesempatan kerja adalah banyaknya lapangan pekerjaan yang tersedia untuk angkatan kerja. Badan Pusat Statistik (BPS) yang dirilis di Jakarta, Jum'at 5 Mei 2017 menyebutkan, tingkat pengangguran terbuka (TPT) menurun pada Februari 2017 sebesar 5,33\%. Persentase ini mengalami penurunan dibanding TPT Agustus 2016, yakni 5,61\% (Roszandi, 2017).

Dengan adanya fakta angka pengangguran yang berkurang serta terserapnya tenaga kerja ini mungkin salah satu latar belakang kenapa siswa jurusan Ilmu msosial mempunyai motivasi untuk memilih peminatan sains. Tidak bisa dipungkiri,sampai saat ini masih banyak siswa SMA yang belom berkesempatan untuk melanjutkan studi ke perguruan tinggi, mereka ada yang masih memilih untuk kembali ke masyarakat, walaupun mereka sebetulnya belum siap untuk terjun ke dunia kerja, sebagaimana halnya siswa SMK. lulusan SMA banyak yang bekerja sebagai tenaga kerja swasta di berbagai tempat, yang mungkin saja memerlukan bekal ilmu selaian ilmu pengetahuan yang mereka dapatkan di jurusan mereka..

Selanjutnya indikator yang mempengaruhi pemilihan peminatan sains yang lain adalah dorongan keluarga yaitu sebesar 62,56 (baik), ini berarti bahwa keluarga sangat berpengaruh dalam menentukan sesuetu begitu juga dengan memilih peminatan,Sebagaimana yang dikatakan oleh (Djaali, 2015) bahwa keadaan keluarga merupakan suatu hal yang sangat menentukan dalam keberhasilan seorang anak dalam belajar.
Disusul oleh indicator peluang melanjutkan studi yaitu sebesar $61,50 \%$ (baik) hal ini berarti bahwa siswa jurusan ilmu sosial mempunyai motivasi untuk melanjutkan studi ke kelompok IPA, Dengan kata lain belum tertutup kemungkinan siswa di jurusan ilmu sosial untuk nmelanjutkan studi ke kelompok disiplin ilmu IPA.

Indikator ekstrinsik berlandaskan dorongan teman hanya sebesar 59,32\% (cukup) artinya seorang siswa tidak mudah untuk dipengaruhi teman dalam memilih peminatan sains. Berarti masing - masing siswa mempunyai prinsip dalam mengambil keputusan untuk memilih lintas minat, dengan arti kata para siswa mempunya pertimbangan sendiri dan tidak ikutikutan dengan pendapat teman dalam hal pemilihan lintas minat tersebut.

Hamalik (2005) mengatakan motivasi mendorong timbulnya tingkah laku dan perbuatan. Artinya motivasi merupakan penggerak yang timbul dari dalam diri yang menimbulkan seseorang akan bertindak, hal ini terwujud dalam perilaku. Perilaku inilah yang merupakan pelaksanaan dari keputusan yang telah diambil. Makin tinggi kesadaran siswa dalam pencapaian terhadap sesuatu berarti semakin tinggi pula dorongan untuk melakukan perbuatan. Dengan demikian mereka akan berusaha untuk mengambil keputusan terbaik dalam memilih jurusan agar tercapai tujuan yang telah ditetapkan.

\section{SIMPULAN}

Motivasi instrinsik lebih mempengaruhi siswa kelas $\mathrm{X}$ Jurusan Ilmu Sosial SMA N I Kecamatan Suliki dalam memilih lintas minat sains dari pada motivasi ekstrinsik. 
DAFTAR PUSTAKA

Ade M., Hertien RR, K., Adi S.,Y. (2014). Motivasi Siswa Kelompok Peminatan Ilmu-Ilmu Sosial Terhadap Pelajaran Biologi Sebagai Mata Pelajaran Lintas Minat. Jurnal.Bandung: Program Studi BiologiUniversitas Pendidikan Indonesia

Dimyati \& Mudjiono. (2002). Belajar dan Pembelajaran. Jakrta : Depdikbud

Djaali. (2011). Psikologi Pendidikan. Jakarta: Bumi Aksara

Gilarso, T. (2008). Pengantar Ilmu Ekonomi Makro. Yogyakarta: Penerbit Kanisius

Hamalik, O. (2005). Kurikulum dan Pembelajaran. Jakarta: Bumi Aksara

Uno, H, Mohamad, N., \& Ispurwanti, D. (2012). Belajar dengan Pendekatan Pailkem. Jakarta: Bumi Aksara

Kemendikbud. (2013). Peminatan Peserta Didik SMA dan SMK. Jakarta : Kementrian Pendidikan dan Kebudayaan

Kemendikbud. (2015). Model Penyelenggaraan Peminatan. Jakarta : Kementrian Pendidikan dan Kebudayaan

Peraturan Menteri Pendidikan dan Kebudayaan Republik Indonesia. 2013. Peraturan Menteri Pendidikan dan Kebudayaan Republik Indonesia Nomor 69 Tahun 2013 Tentang Kerangka Dasar dan Struktur Kurikulum. Jakarta: Pemerintah Republik Indonesia

Riduwan. (2011). Belajar Mudah Penelitian untuk GuruKaryawan dan Peneliti Pemula. Bandung: Alfabeta
Roszandi, D. (2017). Angka Pengangguran Menurun pada Februari 2017. TEMPO.CO.

Sardiman, A.,M. (2010). Interaksi \& Motivasi Belajar Mengajar. Jakarta: PT Rajagrafindo Persada 